\title{
Hegemonial Evaluation of Importance of Women Education and their Socio Economic Development in Fika Local Government Area, Yobe State, Nigeria
}

\author{
Umar Saleh Baba \\ Department of Sociology \\ Yobe State University, Damaturu, Nigeria. \\ Blessing Ijeoma Anumaka \\ Kampala International University ,Uganda
}

\begin{abstract}
The paper discussed the importance of women education and the socio economic development in Fika local government area of Yobe state, Nigeria. The paper focused on the concept of women education, the concept of socio-economic development and the importance of women education in socio-economic development. This study employed quantitative approach with descriptive correlation design and also the total population of 66901 and the sample size of 382 respondents while questionnaire and interview guide were used as research instruments to collect required data.The study also used sample of 382 respondents, frequency and percentage techniques, means and standard deviation and finally, Pearson linear correlation co-efficient (PLCC) to establish the relationship between women education and the element of socio economic development in Fika local government area of Yobe state. The findings of this study revealed that there is positive and very significant relationship between women education and their household income level, and a positive relationship exist with standard of living, economic development and women education but this is not significant. The recommendation of this study is that all effort to empower women should be directed toward educational empowerment in the state as this is significant to overall economic growth in the state. This is because women education in terms of socio-economic development have significant effect on their family,social and economic development of a nation as a whole..
\end{abstract}

Keywords: women education, Sociology, socio-economic development, economic growth,

\section{INTRODUCTION}

Women traditionally had been regarded as inferior to men physically and intellectually (Snyder, 2006) both law and theology had order this objection. Women were long considered naturally weaker than men, squeamish and unable to perform work that requires muscular or intellectual development. Men seem to have a cultural dominance over women thus making women and their families reluctant to struggle in certain areas of economic progression. Traditionally a middle-class girl in western Nigerian culture tended to learn from her mother example like cooking, cleaning and caring for younger children, as the behaviour expected of her when she grows up. In most pre-industrial societies, for example, domestic chores were relegated to women. Leaving heavier labour such as hunting and ploughing to men (Birdsal et al, 2005).The educational imbalance against female gender is a well-known fact at the primary, secondary and tertiary levels, and the disparities in education also affect the labour market. It is widely acknowledged that women produce the largest percentage of global wealth (UN, 2013), but in certain states or country, they are denied a fair share of that wealth. As a result of male dominated ownership and control of resources, the income levels and standards of living 
of women is tied to the decisions and choices of men- a hegemonial advantage. According to the U N Human Development Report for Nigeria (2013), poverty is $14 \%$ higher in women-led households as compared to male-led households. Employment opportunities are tailored along gender lines, where women have lower opportunities of gaining employment than men.

\section{The concept of women education}

Education is the process of imparting knowledge, skills and disposition to the learner, (Hanushek 2008). On the other hand, women education refers to the process of improving women's life through the inculcation of desirable skills, knowledge and societal cherish, values through learning and research process (Sen 2009).

Cambridge conference on African education 1956,found women education as the united concern of all people for the right upbringing of their children and the improvement of its national life. Durkheim( 1956:25) states:

"women education is the influence exercised by adult women generations on those that are not yet ready for social life. Its object is to arouse and develop in a child a certain number of physical and moral states which are demanded of them by both the political society as a whole and the special milieu for which they are specially destined.

Women education fosters the development of intellectual capabilities of women and increases their reasoning powers. This is done through the impartation of knowledge of principle which aids the development of the intellect. In the psycho-motor dimension, education promotes desirable physical development. Quite a number of women learn to appreciate those practices and habit that can lead to enviable status of physical health. The effective dimension of women education is concerned with the building of right attitude, values and norms usually inculcated at home through informal education or oral tradition..

Women education is a complicated debate and it is a complex set of issues and discourse surrounding education.(primary education, secondary education, tertiary education and health education in particular) for girls and women. It includes areas of gender education and access to education and its connection to the alleviation of poverty. The issue of single sex education and religious teachings on education which have been traditionally dominant are still highly relevant in contemporary discussions of female education as a global consideration (klasen 2013).

One study has shown that an educated girl will invest 10-20 times more income back into her family and community than a man would. Girls who receive an education marry at an older age, have fewer children, and are more likely to seek health care for themselves and their children. Even so, nearly 250million adolescent girls live in poverty and those figures are associated with illiterate girls. Today, fewer than two percent of every international development dollars goes to girls, the very people who have the capacity to make an impact on ending poverty. As long as girls remain invisible, the world misses out on a tremendous opportunity for change (Levine et al, 2013).

Better lives for girls mean better lives for everyone in their communities - their brothers, fathers, future husbands and sons. When you improve a girl's life through education, health, safety and opportunity, these changes have a positive ripple effect (Levine,2013).As an educated mother, active, productive citizen and prepared employee, she is the most influential force in her community to break the circle of poverty. Feminist movement has certainly promoted the importance of the issues attached to female education; the discussion is wide ranging and by no means narrowly defined. It may include for example: AIDSs education, 
universal education and so many other types/ State provided primary and secondary education independent of gender is not yet a global norm, even if it is assumed in most developed countries. In some western countries, women have surpassed men at many levels of education. For example, in the united states in 2005/2006, women earned 62\%of Associate degrees, $58 \%$ of Bachelor's degrees, $60 \%$ of Masters degrees, and 50\% of Doctorates (Dollar and Gatti, 2013).

Education for women with handicaps has also improved. In 2011, Guisi Spagnolo became the first woman with Down Syndrome to graduate from college in Europe (she graduated from the University of Palermo in Italy). Improving women education levels has been demonstrated to have clear impacts on the health and economic future of the young women, which in turn improves the prospects of their entire community. In the poorest countries of the world, 50\% of women did not attend secondary school. Yet, research shows that every extra year of school for girls increases their life time by $15 \%$. Improving female education, and thus the earning potential of women, improve the standard of living of their own children, as women invest more on their income in their families than men do (King and Hill, 2013).

According to Klasen (2013), African countries, such as Burkino Faso, girls are unlikely to attend schools for such basic reasons as a lack of latrine facilities for girls. Recent research in human development has established a strong link between women's education and socioeconomic development yet, women's education is one of the major explanatory variables behind the rate of socio-economic development (Klasen, 2013). This assertion has shown that socioeconomic status has a positive correlation with most of the factors or sub variables of education or its indicators. According to notable economist Lawrence summers, investment in higher levels of education for girls may well be the highest return on investment available in the developing world.

\section{Effects of women education on economic development}

Both individuals and countries benefit from women's education. Individuals who invest in education receive a net monetary gain over the course of their lifetime ( Dollar and Gatti,2008). According to Harry Patrinos, a lead education economist at the World Bank, the profitability of education, according to estimates of private rate of return, is indisputable, universal, and global. The principle holds particularly for women, who can expect a 1.2\% higher return than men on the resources they invest in education. Providing one extra year of education to girls increases their wages by $10-20 \%$. This increase is $5 \%$ more than the corresponding returns on providing a boy with an extra year of schooling.

This female individual's monetary gain creates an increase in the overall economic productivity of a country. Girls are underrepresented in schooling, meaning that investments aimed specifically at educating women should produce bigger dividends. Although investment in women's education is not present everywhere. Dollar and Gatti (2008) have presented findings that show that this decision, along with other failures to invest in women are not "an efficient economic choice for developing countries" and that "countries that under-invest grow more slowly. Further to their findings and a cursory examination and a holistical observation at the opportunity cost of not investing in girls, the total missed GDP growth is between $1.2 \%$ and $1.5 \%$. When looking at different regions, it is estimated that $0.4-0.9 \%$ of the difference in GDP growth is accounted for solely by differences in the gender gap in education. The effect of the educational gender gap is more pronounced when a country is only moderately poor. Thus, the incentive to invest in women goes up as a country moves out of extreme poverty. 
In addition to total economic growth, women's education also increases the equitability of the distribution of wealth in a society. Increased women's education is important for achieving this as it targets the impoverished women, a particularly disadvantaged group. There is also evidence that lower gender disparity in educational attainment for a developing country correlates with lower overall income disparity within society.

\section{Effects of women education on social development}

According to Klasen (2013) women's education leads to significant social development. Some of the most notable social benefits include decreased fertility rates and lower infant mortality rates, and lower maternal mortality rates. Closing the gender gap in education also increases gender equality, which is considered important both in itself and because it ensures equal rights and opportunities for people regardless of gender. Women's education has cognitive benefits for women as well. Improved cognitive abilities increase the quality of life for women and also lead to other benefits. One example of this is the fact that educated women are better able to make decisions related to health, both for themselves and their children. Cognitive abilities also translate to increased political participation among women. Educated women are more likely to engage in civic participation and attend political meetings, and there are several instances in which educated women in the developing world were able to secure benefits for themselves through political movements. Evidence also points to an increased likelihood of democratic governance in countries with well-educated women.

There are also benefits relating to the woman's role in the household which has been observed literally. Educated women have been found to experience less domestic violence, regardless of other social status indicators like employment status. Women with an education are also more involved in the decision-making process of the family and report making more decisions over a given time period. In particular, these benefits extend to economic decisions. Besides the intrinsic value of increasing a woman's agency, having women play a more active role in the family also brings about social benefits for family members. In a household where the mother is educated, children and especially girls are more likely to attend school. In households where a mother is not educated, adult literacy programs can indirectly help to teach mothers the value of education and encourage them to send their children to school There are also a number of other benefits for children associated with having an educated mother over having only an educated father, including higher survival rates and better nutrition.

\section{RESEARCH METHODOLOGY}

The study employed a quantitative approach and a descriptive correlation design. Descriptive because it is interested in testing the relationship between the importance of women education and socio-economic development. It also employed quantitative approaches because data was collected and analyzed in quantitative method.

The research population includes women's group within Fika local government area. According to 2006 census, Fika had the population of 66901 women from this population, the study focused on various categories such as women's political leaders, cultural leaders, as well as members of the civil society. It was from this that the sample size of 382 were randomly selected. The sample for this study sample were chosen from among the various clusters of people (political leaders, religious leaders, cultural leaders as well as members of the civil society). The respondents were chosen because of their vast knowledge and familiarization with the situation on ground in the area of study. The researcher used the krejcie and Morgan (1970) sample determination table. 
Table 1: Sample selection table

\begin{tabular}{|l|c|c|}
\hline Category & Population & Sample \\
\hline Political leaders & 100 & 60 \\
\hline Religious leaders & 100 & 60 \\
\hline Cultural leaders & 100 & 60 \\
\hline Civil society members & 100 & 60 \\
\hline FOMWAN officials & 200 & 142 \\
\hline Total & $\mathbf{6 0 0}$ & $\mathbf{3 8 2}$ \\
\hline
\end{tabular}

Considering the large number of the research population, the researcher used stratified and simple random sampling techniques to select the required sample for the study. Stratified sampling was used to select the respondents from among the various clusters or categories, and then simple random sampling was used to select respondents because, using this method everybody had an equal chance of being selected for the study, thereby allowing the researcher to minimize bias in sample selection.The researcher used researcher made- questionnaires on importance of women education and socio-economic development. The questionnaire was closed ended questions relating to the topic of study. The collected data was mainly from key informants and other respondents who were illiterate enough to give answers to questionnaire items

\section{DATA ANALYSIS}

In analyzing the data, the information obtained was re-arranged, coded according to the type of information. The researcher used a sample frequency and percentage techniques to analyze the personal data of the respondents. The means and standard deviation were also used to rate the level of their education and socio-economic development. This study also used Pearson's linear correlation co-efficient (PLCC) to correlate the relationship between women education and socio-economic development of women in Fika local government Yobe state, Nigeria.

Table 2: Pearson's correlation for women education and socio-economic development

\begin{tabular}{|l|c|c|c|c|}
\hline Variables co related & R-Value & Sig. & Interpretation & Decision on Ho \\
\hline $\begin{array}{l}\text { Women education Vs. House } \\
\text { hold income }\end{array}$ & .124 & 0.018 & $\begin{array}{c}\text { Significant } \\
\text { correlation }\end{array}$ & Rejected \\
\hline $\begin{array}{l}\text { Women education Vs. standard } \\
\text { of living }\end{array}$ & .038 & 0.474 & $\begin{array}{c}\text { Insignificant } \\
\text { correlation }\end{array}$ & Accepted \\
\hline $\begin{array}{l}\text { Women education Vs, overall } \\
\text { socio-economic development }\end{array}$ & 0.87 & 0.109 & $\begin{array}{c}\text { Insignificant } \\
\text { correlation }\end{array}$ & Accepted \\
\hline
\end{tabular}

\section{DISCUSSION OF FINDINGS}

The finding of this study revealed a positive significant correlation between women education and their socio-economic development in Fika local government area of Yobe state, but there was no significant correlation with other related factors. These findings are in agreement with several other researchers on women education; For example , Amatyasen (2009) indicated that there is a direct relationship between women's education and socio-economic development and if more women acquire education the inequality between men and women reduces and yet it has been argued that gender discrimination or hegemonic dominance is a hindrance to socio-economic development. The findings are also in line with what is indicated by World Bank (2013) that achieving quality of education is a pre-requisite to achievement of other development indicators. Gender inequality or cultural hegemony which still exists,reduces with increased socio-economic development, for which men and women benefit. According to Klasen (2013), women education is a major explanatory variable of socio-economic development and has a positive correlation with it. Hanushek (2008) indicate that investing in higher levels of education for girls has got a highest return on investment for developing 
countries and they are likely to benefit more from women education. Since education has been proved to be an investment and a catalyst of economic development.

\section{CONCLUSION AND RECOMMENDATIONS}

Women education in general has got a significant predictive strength over socio-economic development. An increase in women education in general will always increase the speed of socio-economic development in their family and the opposite is true. Based on the findings of the study, all efforts to emancipate women should be directed towards educational empowerment especially in western and even northern part of Nigeria. If there is any other kind of emancipation, then it should come after education empowerment.

\section{References}

Birdsal, (2005). “Towards universal primary education; investments, incentives and institutions” European journal of education 40, no: 337-349.

Dollar, D. and Gatti, R.(2013). Gender inequality, income and growth: are good times good for women? Washington D.C; the World Bank.

Durkheim,E. (1996 Revised).Education and sociology, New York: The free press.

Hanushek, E. (2008). Schooling gender equity and economic outcomes in girls education in the $21^{\text {st }}$ century gender equity empowerment and economic growth. Washington D.C; World Bank.

Klasen, s. (2002). "Low schooling for girls, growth for all cross country evidence on the effect of gender inequality in education on economic development .The World Bank economic review 16, no. 30: 345-373"

Levene, E. (2013). Girls count: a global investment and action agenda Washington D.C: centre for global development.

Nigerian National population census Report 2006.

Patrinos, H. (2013) "Returns to education: the gender perspectives" in the girls education in the $21^{\text {st }}$ century: gender equity, empowerment, and economic growth.

Sen, A. (2009). Human Development in Perspective; Oxford University Press.

Snyder, M. (2006) "Unlikely godmother: the UN and the global women's movement" in Myra max ferret and Aili Marie tripped, global feminism, transnational women's activism organizing and women's right, New York: NYU Press. 